\title{
MODIFIKASI PATI BIJI ALPUKAT (PERSEA AMERICANA MILL.) MENGGUNAKAN RAGI TAPE (SACCHAROMYCES CEREVISAE)
}

\author{
I Sukma, Mohammad Fuad Fauzul Mu'tamar*, Asfan Asfan \\ Program Studi Teknologi Industri Pertanian, Universitas Trunojoyo Madura \\ Email : mfuadfm@gmail.com
}

\begin{abstract}
Avocado seed has many useful substances such as starch, Avocado seeds also have a starch percentage 23\%. Natural starch has a limited application because it not applicative. Because of this, modification was required to improve the function of the starch, which is by modifying the starch with fermentation. The factors that influence the material modification process are yeast concentration and fermentation duration. The purpose of this study was to determine the effect of yeast concentration and duration of fermentation on types of avocado seed starch. The study design used by Factorial Design (RALF) with two factors: yeast concentration 0\%, 6\%, 8\% and fermentation time 24 hours, 48 hours, 72 hours. The research parameters included measuring gelatiniation time, gelatinasation temperature measurement, $\mathrm{pH}$ test and viscosity test. The results showed that the fermentation time with yeast concentration have a significant effect on $\mathrm{pH}$ of the material, gelatinization temperature, viscosity and starch granules. Based on the pH test parameters, the starch which had the lowest pH was $8 \%$ yeast measurement with 72 hours fermentation time (zc) that is 5.4.
\end{abstract}

Keyword: avocado seed starch, yeast concentration, time fermentation

\section{PENDAHULUAN}

Buah alpukat (Persea americana mill.) merupakan buah yang memiliki banyak manfaat. Data yang disajikan oleh Statistics Division Of The Food And Agriculture Organization Of The United Nations, melaporkan bahwa total produksi buah alpukat dunia dari tahun 1993 sampai 2013 sejumlah 4,71 juta ton. Sedangkan berdasarkan data yang disajikan Direktorat Jenderal Hortikultura tahun 2014, produksi buah alpukat di Indonesia sebesar 307,318 ton. Bagian yang dikonsumsi dari buah alpukat adalah bagian daging buahnya saja. Sedangkan bagian kulit dan biji dikatagorikan sebagai limbah. Pertanian yang dibuang tanpa aplikasi lebih lanjut. Persentase berat buah biji alpukat sekitar 13\% dari total berat segar buah. Maka jika diasumsikan berdasarkan total produksi buah alpukat di Indonesia, maka jumlah biji alpukat yang dibuang pada tahun 2014 adalah 39,951 ton.

Biji alpukat yang dianggap limbah, memiliki kandungan pati sebesar $23 \%$ (Candra et al, 2013). Kandungan pati yang cukup tinggi ini memungkinkan pati biji alpukat untuk dijadikan alternatif sumber pati sebagai bahan baku produk bernilai tambah. Pati biji alpukat di kondisi alaminya cukup sulit untuk diaplikasikan dalam pembuatan produk tertentu misalnya dibuat edible film. Pati untuk edible film harus memiliki daya lekat dan daya elastisitas yang tinggi, sehingga sebelum pati tersebut digunakan perlu dilakukan modifikasi pati agar bisa diaplikasikan. Modifikasi pati biasanya dilakukan dengan perlakuan khusus, salah satunya dengan proses fermentasi untuk meningkatkan fungsionalitas pati. 
Berdasarkan uraian tersebut, limbah biji alpukat yang melimpah dapat dimanfaatkan menjadi alternatif pati. Proses fermentasi biasanya dilakukan dengan memanfaatkan mikroorganisme tertentu untuk merombak karakteristik pati yang terbentuk. Salah satu mikroorganisme yang digunakan adalah ragi tape. Penelitian ini dilakukan dengan melakukan proses fermentasi terhadap biji alpukat menggunakan ragi tape. Hasil penelitian diharapkan dapat mengetahui karakteristik pati biji alpukat termodifikasi sehingga bias diaplikasikan lebih lanjut sesuai dengan kebutuhan masyarakat.

\section{METODE}

\section{Alat dan Bahan}

Peralatan yang digunakan di penelitian ini adalah timbangan analitik, pisau, blender, kain saring, loyang, baskom, plastik penyimpanan, ayakan 100 mesh, cabinet dryer, box plastik, panci, dan sendok, hot plate, beaker glass, spatula, viscometer Rion VT-04, pHmeter, kaca preparat, Termometer, Stopwatch, Microscope, pipet, enlenmayer, gelas ukur, kompor gas, panci dan sendok.

Bahan yang digunakan pada penelitian ini adalah biji alpukat dari limbah penjual jus di Kabupaten Bangkalan, ragi Saccharomycaes cerevisae, aquades dan air.

\section{Waktu dan Tempat}

Penelitian dilakukan selama 3 bulan di semester kedua tahun 2018 yaitu pada bulan Mei sampai dengan Juli 2018. Penelitian dilakukan di Laboratorium Teknologi Industri Pertanian, Fakultas Pertanian, Universitas Trunojoyo Madura. Adapun laboratorium yang digunakan meliputi Laboratorium Rekayasa Proses dan Laboratorium Analisis Mutu.

\section{Prosedur Penelitian}

\section{Proses ekstraksi pati biji alpukat}

Proses ekstraski biji alpukat dilakukan dengan metode ektraksi pati dari singkong yaitu dengan cara merajang bahan dan dihaluskan menggunakan blender dengan perbandingan air dan bahan 1:1. Setelah bubur biji sudah didapatkan maka dilakukan pemerasan menggunakan kertas saring. Hasil suspense Pati biji alpukat kemudian di fermentasi menggunakan ragi dengan konsentrasi $6 \%$ dan $8 \%$ dengan lama fermentasi 24 jam, 48 jam dan 72 jam. Setelah pengendapan, maka dilalukan pembilasan dan diendapkan kembali selama 24 jam. Endapan yang diperoleh kemudian dikeringkan dengan suhu 600C dengan waktu 4 jam. Pati yang sudah kering kemudian dihaluskan dan diayak dengan ayakan 100 mesh.

\section{Proses pembuatan gel pati biji alpukat}

Pada Proses pembuatan gel, bahan utama yang dibutuhkan adalah pati biji alpukat dan aquades yang dipanaskan. Pemanasan dilakukan hingga seluruh bagian bahan menjadi gel. Proses pemanasan dilakukan secara tidak langsung yaitu menggunakan water bath dengan perbandingan pati: aquades sebesar $1: 5$.

\section{Pengukuran Waktu Gelatinisasi}

Analisa waktu gelatinisasi dilakukan dengan mencampur pati biji alpukat dengan aquades dengan perbandingan 1:5, kemudian dilakukan proses pemanasan dan diukur menggunakan stopwatch pada saat pemasakan pati. Pati dikatakan masak apabila granula pati pecah dan membentuk gel kemudian dicatat waktunya sebagai waktu gelatinisasi.

\section{Pengukuran Suhu Gelatinisasi}

Analisa suhu gelatinisasi dilakukan dengan menggunakan thermometer pada saat pemasakan pati. Setelah granula pati pecah dan membentuk gel pemanasan dihentikan dan dicatat pada suhu berapa pasta mencapai gelatinisasi terbaik. 


\section{Pengujian $\mathrm{pH}$}

Gel pati biji alpukat diuji $\mathrm{pH}$ nya dengan menggunakan $\mathrm{pH}$ meter digital. Setiap pengukuran $\mathrm{pH}$ dilakukan dengan menggunakan sampel sebanyak 4 gram dengan aquades $4 \mathrm{ml}$. Sampel dan aquades kemudian dimasukkan pada beaker glass. Pengukuran $\mathrm{pH}$ dilakukan secara berurutan berdasarkan kode sampel. $\mathrm{pH}$ meter yang telah digunakan untuk mengukur $\mathrm{pH}$ harus selalu kalibrasi lagi dengan larutan buffer untuk mendapatkan nilai yang sesuai dengan larutan buffernya.

Pengujian viskositas.

Pengujian viskositas gel dilakukan dengan menggunakan viscometer VT-03F. Sampel sebanyak 150gr dimasukkan dalam beaker viscometer. Dalam uji ini probe yang digunakan adalah probe nomor 3 angka dimulai dari 100 d.Pa.s

\section{Granula Pati}

Pengujian granula pati biji alpukat setiap variasi sampel ditimbang sebanyak 1 gram kemudian ditambahkan aquades sebanyak $2 \mathrm{ml}$. Teteskan sampel pada masing-masing preparat yang sudah dilabeli sesuai sampel kemudian lihat bentuk granula pati menggunakan mikroskop.

\section{HASIL DAN PEMBAHASAN \\ Waktu Gelatinisasi Pati}

Waktu gelatiniasi adalah waktu yang dibutuhkan granula untuk menyerap air sampai granula membengkak dan pecah. Gambar 1 adalah hasil pengamatan waktu gelatinisasi pati biji alpukat termodifikasi.

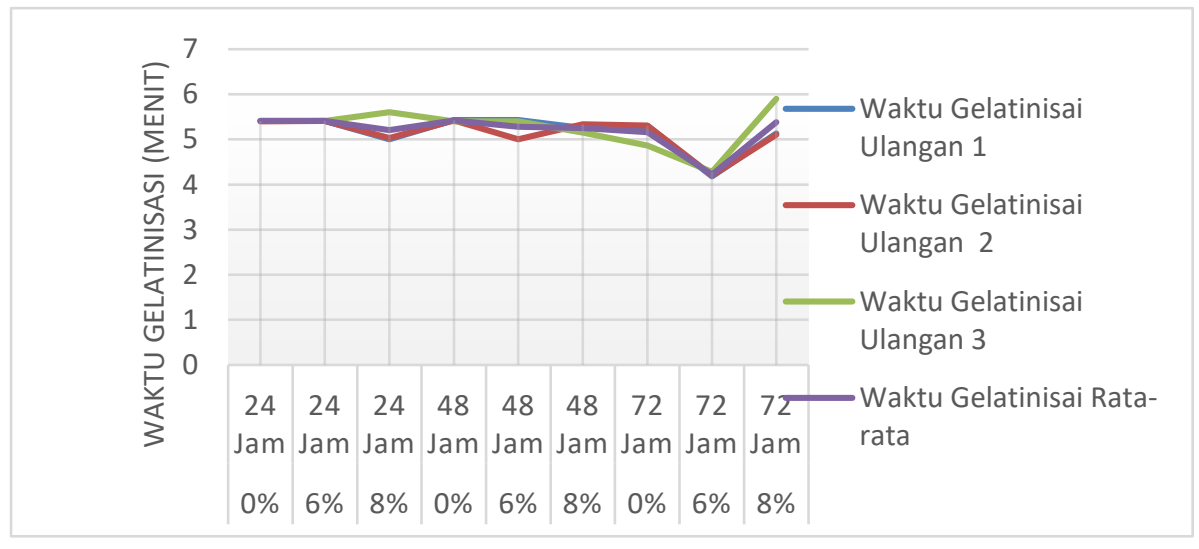

Gambar 1 Grafik Waktu Gelatinisasi Pati Biji Alpukat Termodifikasi

Waktu gelatinisasi mengalami penurunan pada perlakuan tertentu. Pati dengan perlakuan fermentasi 72 jam dengan konsentrasi ragi $8 \%$ menunjukkan waktu gelatinisasi etrcpat dengan waktu 4.2 menit Waktu gelatinisasi yang singkat disebabkan oleh granula pati menyerap air dengan cepat sehingga granula pati mengalami pembengkakan dan pecah. Pecahnya granula pati menyebabkan pati tergelatinisasi. Pati yang cepat tergelatinisasi akan berdampak pada produk yang dihasilkan. (Taylor, 2003).

\section{Suhu Gelatiniasi Pati Biji Alpukat}

Suhu gelatinisasi pada pati biji alpukat termodifikasi cenderung meningkat (Gambar 2). Suhu gelatinisasi menurun pada jam 24-72 dengan kontrol (konsentrasi ragi 0\%). Semakin lama fermentasi menyebabkan pelemahan struktur granula menjadi amorf karena leaching (peluruhan). Perendaman ini menyebabkan pati biji alpukat mudah mengembang dan partikel pati yang dihasilkan mudah tergelatinisasi sehingga suhu gelatinisasi menurun (Aini, 2010). Pada fermentasi dengan waktu 24-72 jam dengan konsentrasi ragi $6 \%$ dan $8 \%$ suhu 
mengalami kenaikan secara signifikan. Suhu tertinggi didapatkan dari perlakuan konsentrasi ragi $8 \%(\mathrm{Z})$ dengan fermentasi 72 jam (C) suhu gelatinisasi yang dicapai adalah sebesar $85^{\circ} \mathrm{C}$. Meningkatnya suhu gelatinisasi ini disebabkan oleh kompleks amilosa yang terbentuk menyebakan pengembangan terhambat sehingga suhu gelatinisasi meningkat.

Meningkatnya suhu gelatinasasi seiring dengan penambahan konsentrasi ragi dan lama fermentasi menunjukkan kecocokan laporan Glicksman (1969) bahwa suhu gelatinisasi dipengaruhi oleh protein dalam bahan, ukuran molekul amilosa, amilopektin serta keadaan media pemanasan. Kadar protein yang tinggi membentuk kompleks dengan amilosa sehingga membentuk endapan yang tidak larut dan menghambat pengeluaran amilosa dari granula. Dengan demikian diperlukan energi yang lebih besar untuk melepas amilosa sehingga suhu gelatinisasi yang dicapai akan lebih tinggi.

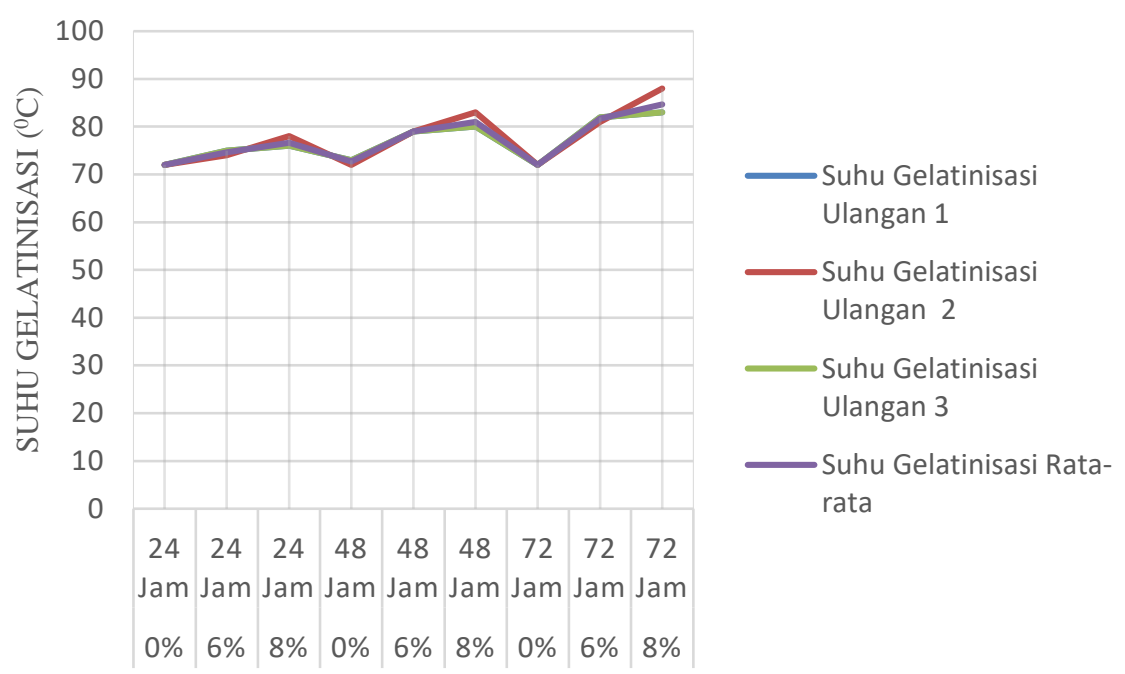

Gambar 2 Grafik Pengukuran Suhu Gelatinisasi Pati Biji Alpukat

\section{pH Pati Biji Alpukat}

Pati biji alpukat termodifikasi memiliki $\mathrm{pH}$ bahan cenderung naik (Tabel 1). Dalam penelitiannya Wignyanto (2001) melaporkan bahwa jumlah sel Saccharomyces cerevisiae akan semakin meningkat seiring dengan lama fermentasi hal ini disebabkan oleh konsentrasi gula reduksi dan peningkatan konsentrasi etanol dalam bahan. Meningkatknya etanol dalam bahan menyebabkan keasaman dan suhu media cenderung meningkat selama fermentasi.

Tabel 1 Pengaruh konsentrasi ragi terhadap ph gelatinisasi pati biji alpukat termodifikasi

\begin{tabular}{cc}
\hline Konsentrasi Ragi & pH Gelatinisasi Pati \\
\hline $\mathrm{X}(0 \%)$ & $5.74444^{\mathrm{a}}$ \\
$\mathrm{Y}(6 \%)$ & $5.7556^{\mathrm{b}}$ \\
\hline
\end{tabular}

\begin{abstract}
$\mathrm{Z}(8 \%)$
$5.7778^{c}$

Keterangan: Nilai rata-rata yang ditandai dengan huruf yang sama menunjukkan tidak berbeda nyata pada taraf $5 \% \mathrm{Uji}$ Tukey.

Sesuai dengan penelitian yang dilakukan Armata et al. (2013), bahwa aktivitas Saccharomyces cerevisiae berpengaruh pada $\mathrm{pH}$ bahan yang dihasilkan semakin tinggi konsentrasi ragi maka $\mathrm{pH}$ bahan semakin meningkat. $\mathrm{pH}$ tertinggi diperoleh dari gelatinisai pati konsentrasi $8 \%$. Hasil uji Tukey pengaruh konsentrasi ragi terhadap waktu gelatinisasi pati biji alpukat termodifikasi menunjukkan bahwa konsentrasi ragi 0\% dan $6 \%$ berbeda nyata. Konsentrasi ragi $0 \%$ dan $8 \%$ berbeda nyata. Konsentrasi ragi $6 \%$ dan $8 \%$ berbeda nyata.
\end{abstract}


Tabel 2 Pengaruh lama fermentasi terhadap $\mathrm{pH}$ gelatinisasi pati bij alpukat termodifikasi

\begin{tabular}{cc}
\hline Lama Fermentasi & $\mathrm{pH}$ Gelatinisasi Pati \\
\hline 24 Jam & $5.4889^{\mathrm{a}}$ \\
48 Jam & $5.6667^{\mathrm{b}}$ \\
72 Jam & $6.1222^{\mathrm{c}}$ \\
\hline
\end{tabular}

Keterangan: Nilai rata-rata yang ditandai dengan huruf yang sama menunjukkan tidak berbeda nyata pada taraf $5 \%$ Uji Tukey.

Hasil uji Tukey pengaruh lama fermentasi terhadap $\mathrm{pH}$ gel pati biji alpukat termodifikasi (Tabel 2) juga menunjukkan bahwa perlakuan lama fermentasi 24 jam menunjukkan perbedaan nyata dengan perlakuan lama fermentasi 48 jam. Begitu juga pada perlakuan lama fermentasi 24 jam dengan lama fermentasi 72 jam. Semakin lama waktu fermentasi maka $\mathrm{pH}$ bahan akan semakin menurun (Azizah, 2012)

\section{Viskositas Pati Biji Alpukat}

Fermentasi pati biji alpukat dengan konsentrasi ragi $6 \%$ dan $8 \%$ pada jam $44-$ 72 menyebabkan viskositas gel cenderung menurun (Tabel 3). Hal ini sejalan dengan hasil penelitian Kustyawati (2013) yang menyatakan bahwa penyebab menurunnya viskositas bahan adalah pertumbuhan kolonisasi Saccaromycaes cerevisiae yang memproduksi enzim amilase sehingga menyebabkan terjadinya hidrolisis amilosa. Amilosa terhidrolisis menyebabkan viskositanya menurun.

Tabel 3 Rata-rata viskositas gelatinisasi pati biji alpukat sebagai efek interaksi antara konsentrasi dan fermentasi

\begin{tabular}{ccl}
\hline Konsentrasi & Fermentasi & \multicolumn{1}{c}{ Viskositas } \\
\hline \multirow{2}{*}{$0 \%$} & 24 Jam & $156.667^{\mathrm{a}}$ \\
& 48 Jam & $170^{\mathrm{a}}$ \\
& 72 Jam & $200^{\mathrm{a}}$ \\
& 24 Jam & $356.667^{\mathrm{b}}$ \\
$6 \%$ & 48 Jam & $323.333^{\mathrm{b}}$ \\
& 72 Jam & $290^{\mathrm{b}}$ \\
& 24 Jam & $390^{\mathrm{b}}$ \\
$8 \%$ & 48 Jam & $300^{\mathrm{b}}$ \\
& 72 Jam & $300^{\mathrm{b}}$ \\
\hline
\end{tabular}

Keterangan: angka dengan huruf yang berbeda menunjukkan berbeda nyata $(P \leq 0,05)$.

Interaksi antara konsentrasi ragi dan lama fermentasi menunjukkan perbedaan nyata pada sampel konsentrasi ragi $0 \%$ dengan sampel konsentrasi ragi $8 \%$ dan tidak menunjukkan perbedaan nyata dengan sampel lainnya. Faktor yang mempengaruhi viskositas pati salah satunya adalah suhu gelatinisasi dan bahan yang ditambahkan.

\section{Granula Pati Biji Alpukat}

Ukuran granula berperan penting dalam proses pengolahan, berkaitan dengan suhu gelatinisasi atau kebutuhan energi yang diperlukan Struktur pati yang rapat mempunyai daya ikat air yang lebih tinggi, selain itu terjadi pemutusan ikatan hidrogen pada rantai linier dan berkurangnya daerah amorf yang mudah dimasuki air. Struktur fisik pati, dalam hal ini adalah granula pati, mempengaruhi sifat pati ketika digunakan dalam produkproduk pangan. Pati dengan ukuran granula kecil memiliki suhu gelatinisasi yang tinggi karena cenderung memiliki ikatan antar molekul yang lebih kuat, akibatnya kebutuhan energi untuk proses gelatinisasi menjadi lebih tinggi. Kenyataannya suhu gelatinisasi tidak hanya dipengaruhi oleh ukuran, tetapi lebih dipengaruhi oleh struktur granula pati tersebut (Herawati, 2011).

Pati butiran biji alpukat berbentuk oval dengan permukaan yang relatif halus dan diameter rata-rata $5-35 \mu$. Patinya nonionik dan tidak berlilin. Kisaran suhu gelatinisasi pati biji alpukat adalah 62$75^{\circ} \mathrm{C}$ (Khan, 1987). Bentuk granula pati biji alpukat dengan perlakuan lama fermentasi 72 jam mempunyai ukuran granula yang lebih besar dibandingkan yang lain. Hal ini sesuai dengan penelitian Lindeboom et al. (2004) yang menyatakan bahwa granula pati yang termodifikasi cenderung mempunyai ukuran besar akan lebih tahan terhadap proses hidrolisis. 
Gambar 3 adalah citra dari granula pati biji alpukat yang dihasilkan.

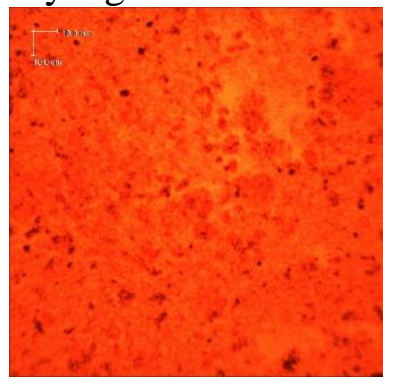

(XA)

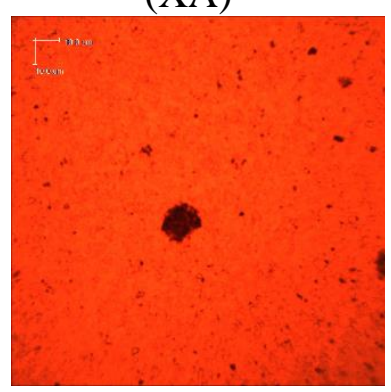

(YA)

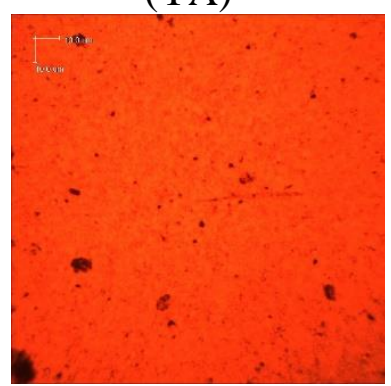

(ZA)

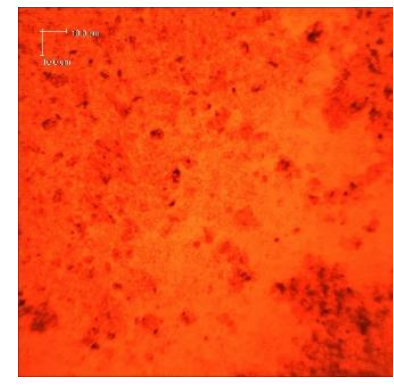

(XB)

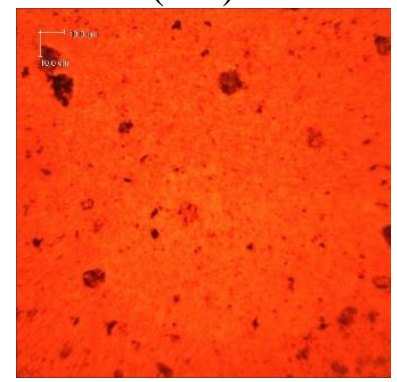

(YB)

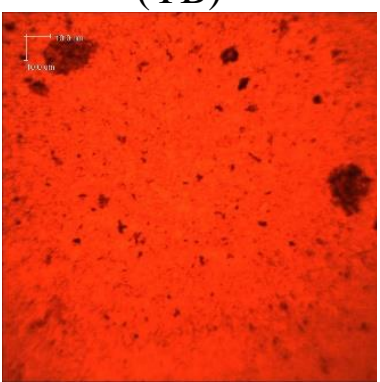

(ZB)

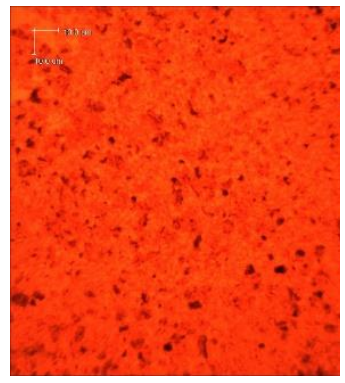

$(\mathrm{XC})$

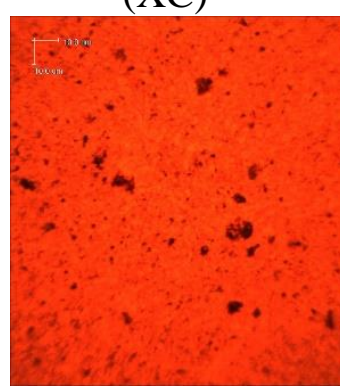

(YC)

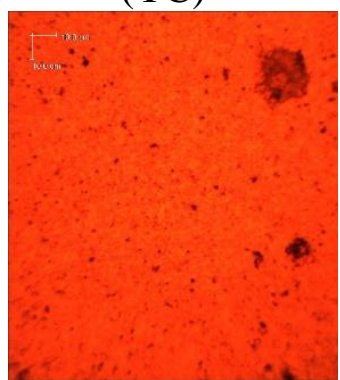

(ZC)

Gambar 3 Bentuk Granula pati berturut-turut dengan Sembilan perlakuan

\section{KESIMPULAN}

Kesimpulan dari penelitian ini dapat dijabarkan sebagai berikut,

1. Konsentrasi ragi dan lama fermentasi berpengaruh terhadap waktu gelatinisasi, suhu gelatinisasi, viskositas, pati yang terbentuk.

2. Pati biji alpukat termodifikasi mempunyai suhu gelatinisasi antara $72^{\circ} \mathrm{C}-85^{\circ} \mathrm{C}$, waktu gelatinisasi 4.22 menit sampai 5.42 menit, sedangkan viskositsnya berkisar antara 157 d.Pa.s sampai 390 d.Pa.s

3. Bentuk granula pati biji alpukat termodifikasi mempunyai ukuran granula yang lebih besar dibandingkan dengan pati tidak termodifikasi.
4. Pati biji alpukat termodifikasi lebih aplikatif dibandingkan dengan pati biji alpukat yang tidak termodifikasi

\section{SARAN}

1. Perlu ada penelitian lanjutan dengan berbagai macam mikroba dan kombinasi waktu fermentasi lebih lama.

2. Perlu adanya penelitian lanjutan mengenai kuat tarik pati biji alpukat termodifikasi

\section{DAFTAR PUSTAKA}

Aini, Nur., Hariyadi, P., Muchtadi, T.R., dan Andarwulan, N. 2010. Hubungan Antara Waktu Fermnetasi 
Grits Jagung Dengan Sifat Gelatinisasi Tepung Jagung Putih Yang Dipengaruhi Ukuran Partikel. Jurnal Teknologi dan Industri Pangan. 21(1): 18-24.

Arnata, I.W., dan Anggreni , A.A.M. 2013. Rekayasa Bioproses Produksi Bioetanol Dari Ubi Kayu Dengan Teknik Ko-Kultur Ragi Tape Dan Saccharomyces cerevisiae.Jurnal Agrointek. 7(1): 21-28.

Azizah, N., Al-Barrii, A.N, dann S Mulyani. 2012. Pengaruh Lama Fermentasi Terhadap Kadar Alkohol, pH, Dan Produksi Gas Pada Proses Fermentasi Bioetanol Dari Whey Dengan Substitusi Kulit Nanas. Jurnal Teknologi Pertanian1(3): 2128.

Chandra, A., H. M. Inggrid dan Verawati. 2013. Pengaruh $\mathrm{pH}$ dan jenis pelarut pada perolehan dan karakterisasi pati dari biji alpukat. Lembaga Penelitian dan Pengabdian kepada Masyarakat. Universitas Katholik Parahyangan. Bandung

Glickmans, M. 1969. Gum Technology in Food Industry. New York: Academic Press, Inc.

Herawati D., Andarwulan, N., Kusnandar, F. 2011. Analisis Paangan. Jakarta: Dian Rakyat
Khan, V. 1987. Characterization of Starch Isolated from Avocado Seeds. Journal of Food Science.52(6): 39-48 Kustyawati, M. E., Sari, M., dan Haryati, T. 2013. Efek Fermentasi dengan Saccharomyces cerevisiae Terhadap Karakteristik Biokimia Tapioka. Jurnal AGRITECH. 33 (3): 281 287.

Lindeboom, N., Chang, P. R. and Tyler, R. T. 2004. Analytical, biochemical and physicochemical aspects of starch granule size, with emphasis on small granule starches: A Review. Starch/Starke, 56: 89-99.

Mahawan, M.A, Tenorio, M.F., Gomez J.A., Bronce, R.A. 2015. Characterization of Flour from Avocado Seed Kernel. Asia Pasific Journal. 3(4): 34-40

Taylor. 2003. Chemical and Functional Properties of Food Components Series. Boca Raton : CRC Press

Wignyanto, Suharjono, dan Novita. 2001.Pengaruh Konsentrasi Gula Reduksi Sari Hati Nanas Dan Inokulum Saccharomyces cerevisiae Pada Fermentasi Etanol. Jurnal Teknologi Pertanian. 1 (1): 68-77 